\title{
SELAYANG PANDANG \\ IMPLIKASI ALIRAN PENDIDIKAN KLASIK
}

\author{
Meidawati Suswandari \\ Universitas Veteran Bangun Nusantara Sukoharjo \\ J1. Letjend. S. Humardani No.1 Sukoharjo \\ E-mail: moetismeida@yahoo.co.id
}

\begin{abstract}
Abstrak - Manusia adalah mahluk yang sempurna dan mengalami perubahan dan perkembangan. Diantara teori-teori perkembangan klasik dalam pendidikan antara lain : 1) Teori Empirisme yang dikemukakan oleh Jhon Locke. Teori ini berpendapat bahwa perkembangan manusia dipengaruhi oleh pengalaman, pendidikan atau lingkungan, tidak dari factor turunan orang tuanya. b) Teori Nativisme yang dikemukakan oleh Athur Schopenhauer. Teori ini berpendapat bahwa sifat-sifat manusia tergantung dari bawaan sejak lahir atau bawaan dari orang tuanya. c) Teori Konvergensi yang dikemukakan oleh William Stem. Teori ini merupakan penggabungan dari teori sebelumnya, yaitu penggabungan dari factor turunan orang tua dan pendidikan. Dengan berjalannya kehidupan manusia yang semakin dinamis, baik pola pikir, ilmu pengetahuan serta teknologi, aliran konvergensi pada umumnya diterima secara luas sebagai pandangan yang tepat dalam memahami tumbuh kembang manusia. Meskipun demikian terdapat variasi mengenai faktor-faktor mana yang paling penting dalam menentukan tumbuh kembang dalam setiap proses pendidikan.
\end{abstract}

Kata Kunci: empirisme, nativisme, konvergensi

\begin{abstract}
Man is a creature of perfect, changes and developments every time. Among the classic developmental theories in education are: 1) the theory advanced by Empiricism Jhon Locke. This theory argues that human development is influenced by experience, education or the environment, not from factor derivative of his parents. $b$ Nativism) theory advanced by Athur Schopenhauer. This theory argues that the nature of the man hanging from a congenital innate from birth or from his parents. c) Convergence Theory propounded by William Stem. This theory is the merging of the previous theories, i.e. the incorporation of the derivative factor parents and education. With the passage of human life that is increasingly dynamic, good mindset, science and technology, the convergence of flow at large is widely accepted as the proper view in understanding human flower growing. However there are variations as to the factors which are most important in determining the growing swell in every educational process.
\end{abstract}

Keywords: empiricism, nativism, convergence 


\section{PENDAHULUAN}

Ada seorang tokoh filosof China klasik Kong $\mathrm{Fu}$ Che menyatakan bahwa "belajar merupakan intisari hidup, hidup manusia yang selalu belajarlah yang dapat meningkatkan kualitas hidup. Kita itu hidup untuk saat ini, bermimpi untuk masa depan dan belajar untuk kebenaran abadi". Artinya bahwa belajar itu bukanlah harus dipandang sebagai suatu kewajiban namun suatu kebutuhan, belajar merupakan suatu proses yang tiada akhir, terusmenerus, dan penuh kesadaran. Belajar itu kunci sukses untuk menghadapi hidup dan kehidupan, mati dan kematian. Belajar merupakan proses perubahan yang berlangsung terus menerus sepanjang hayat tanpa mengenal usia. Sesuai dengan hadits nabi "tuntutlah ilmu sejak dari buaian sampai liang lahat" (H.R Bukhari) ini merupakan dasar belajar merupakan suatu proses yang terus-menerus tiada henti atau "long life education". Semangat belajar, kewajiban belajar ada pada setiap diri manusia, baik untuk laki-laki maupun wanita, untuk yang tua ataupun yang muda, mulai dari lahir hingga nafas berakhir.

Belajar sepanjang hayatnya manusia yang merupakan sebuah kebutuhan, kesadaran, dan adanya perubahan, mengingatkan kita pada aliran klasik pendidikan. Salahsatunya bahwa manusia belajar merupakan akibat adanya kesadaran interaksi antara stimulus dan respon. Seseorang dianggap telah belajar sesuatu jika dia dapat menunjukkan perubahan perilakunya setelah adanya stimulus dan respon yang diberlakukan. Menurut teori behaviorisme dalam belajar yang penting adalah input yang berupa stimulus dan output yang berupa respon. Teori belajar behavioristik ini merupakan proses perubahan tingkah laku sebagai akibat adanya interaksi antara stimulus dengan respons yang menyebabkan siswa mempunyai pengalaman baru. Pengalaman baru inilah yang kemudian dalam aliran pendidikan klasik menyebutkan dirinya sebagai aliran pendidikan yang berkonsep Empirisme.

Aliran empirisme mengacu pada psikologi behavioristik yang menyatakan bahwa setiap individu mendapat proses pendidikan karena adanya pengaruh dari luar. Pavlov juga menyimpulkan bahwa hasil eksperimennya itu juga dapat diterapkan kepada manusia untuk belajar. Implikasi hasil eksperimen tersebut pada kegiatan belajar manusia adalah bahwa belajar pada dasarnya membentuk asosiasi antara stimulus dan respons secara reflektif, proses belajar akan berlangsung apabila diberi stimulus bersyarat (M.Hamid, 2002:74).

Secara definisi bahwa stimulus-respons yaitu suatu proses yang memberikan respons tertentu terhadap apa yang datang dari luar individu. Seseorang dianggap telah belajar sesuatu jika ia mampu menunjukkan perubahan tingkah laku dari stimulus yang diterimanya (Muhaimin dkk, 2002: 196).

Belajar dapat terjadi dengan dibentuknya hubungan, atau ikatan, atau asosiasi, atau koneksi netral yang kuat antara stimulus dan respons. Untuk dapat mencapai hubungan antara stimulus dan respons ini, perlu adanya kemampuan untuk memilih respons yang tepat, serta melalui usahausaha atau percobaan-percobaan (trials) dan 
kegagalan-kegagalan (errors) terlebih dahulu. Tokoh dalam teori koneksi belajar ini ditularkan oleh Thorndike Berdasarkan hal ini, Thorndike mengutarakan bila bentuk paling dasar dari belajar adalah trial and error learning atau selecting-connecting learning dan berlangsung menurut hukum-hukum tertentu (M.Z.Roziqin, 2007:14).

Perubahan belajar seseorang di atas yang mengilhami adanya stimulus dan respon merujuk kita pada pemahaman seperti apa dan bagaimana implikasi aliran pendidikan klasik sebagai upaya menentukan pola dan proses belajar seseorang dalam setiap langkah kehidupannya.

\section{METODE PENELITIAN}

Penelitian ini dilakukan melalui studi pustaka dengan mengumpulkan sejumlah bukubuku, makalah, jurnal, lefleat, majalah yang berkenaan dengan masalah pendidikan aliran klasik. Data yang diperoleh berasal dari dokumen pribadi yang berupa bahan-bahan orang yang mengucapan dengan kata-kata mereka sendiri (Arief Furqon, 1992: 23). Sehingga dalam pengumpulan data dengan mengidentifikasi wacana dari buku-buku, makalah atau artikel, majalah, jurnal, Koran, internet (web), ataupun informasi lainnya yang berhubungan dengan aliran pendidikan klasik. Adapun analisis data menggunakan analisis deskriptif, analisis isi, dan analsisis kritis. Analisis deskriptif yaitu mengumpulkan dan menyusun data kemudian dianalisis data tersebut. Analisis isi yaitu memanfaatkan seperangkat prosedur untuk menarik kesimpulan dari sebuah dokumen yang telah diperoleh. Sementara itu analisis kritis yaitu penafsiran pada teks dan menyikapi makna dibalik suatu peristiwa secara ilmiah.

\section{HASIL DAN PEMBAHASAN}

Mengimplikasi dari manusia yang selalu mengalami proses belajar yang senantiasa membutuhkan stimulus kemudian baru muncul adanya respon, pada dasarnya jika dikaitkan dunia pendidikan khususnya dalam pembelajaran sebagai akibatnya guru memiliki peran yang dominan dalam memberikan pengaruh pada anak didik (siswa). Siswa dalam hal ini dianggap sebagai individu yang tidak membawa apa-apa dan butuh untuk disosialisasi. Pengaruhnya dalam pembelajaran guru dengan siswa memiliki hubungan yang bersifat satu arah.

Berikut ini, gambaran dari interaksi edukatif satu arah yang penulis kutip dalam buku Sosiologi Pendidikan Ravik Karsidi (Meidawati S, 2016: 53). Jika dalam pendapat Ravik Karsidi memberikan istilah interaksi edukatif satu arah. Mengapa demikian? Karena guru yang pro-aktif memberikan stimulus, dengan harapan adanya respon dari siswa. Sedangkan siswa belum dianggap individu yang pro-aktif karena respon yang muncul dari siswa setelah guru melakukan rangsangan (stimulus) terlebih dahulu. Aliran empirisme ini mengacu pada prinsip connectinisme. Guru dalam hal ini berperan sebagai komunikasi satu arah, menempatkan guru sebagai pemberi aksi, Anak didik/siswa sebagai penerima aksi. Oleh sebab itu, peran guru cenderung aktif dan peran anak didik pada posisi pasif. 
Berikut ini pola interaksinya: Pola Guru

- Anak Didik.

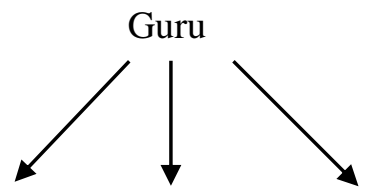

Komunikasi sebagai aksi ( satu arah)

Anak Anak Anak

. Selanjutnya implikasi yang melekat pada proses belajar dari Thorndike ini, salahsatunya bahwa guru dan siswa saling mengkoneksi satu sama lainnya. Sebagai contoh, sebelum guru dalam kelas mulai mengajar, diharapkan anakanak disiapkan mentalnya terlebih dahulu. Misalnya anak disuruh duduk yang rapi, tenang dan sebagainya. Selain itu, guru juga mengadakan ulangan yang teratur, bahkan dengan ulangan yang ketat atau sistem drill. Guru adakalanya memberikan bimbingan, pemberian hadiah, pujian, bahkan bila perlu hukuman sehingga memberikan motivasi proses belajar mengajar.

Seperti halnya dengan Thorndike, tokoh berikutnya Pavlov dan Watson yang menjadi tokoh teori ini juga percaya bahwa belajar pada hewan memiliki prinsip yang sama dengan manusia. Belajar atau pembentukan perilaku perlu dibantu dengan kondisi tertentu (W.Sanjaya, 2006: 69). Kondisi tertentu ini diistilahkan dengan Clasiccal conditional. Sekedar mengingatkan kembali pada argument Pavlov yang berawal dari percobaan laboratoris terhadap anjing. Dalam percobaan ini, anjing diberi stimulus bersyarat sehingga terjadi reaksi bersyarat pada anjing. Anjing tersebut diberi makanan dan diberi lampu. Pada saat diberi makanan dan lampu keluarkan respon anjing tersebut berupa keluamya air liur. Demikian juga jika dalam pemberikan makanan tersebut disertai dengan bel, air liur tersebut juga keluar. Pada saat bel atau lampu diberikan mendahului makanan, anjing tersebut juga mengeluarkan air liur. Makanan yang diberikan tersebut oleh Pavlov disebut sebagai perangsangan yang bersyarat, sementara bel atau lampu yang menyertai disebut sebagai perangsang bersyarat.

Implikasi teori Pavlov penulis gambarkan misalnya pada awal tatap muka antara guru dan murid dalam kegiatan belajar mengajar. Seorang guru menunjukkan sikap yang ramah dan memberi pujian terhadap murid-muridnya sehingga para murid merasa terkesan dengan sikap yang ditunjukkan gurunya.

Merujuk dari teori Pavlov adanya pujian atau penguatan verbal maupun non verbal pada siswa tersebut, muncul adanya pemikiran bahwa pada diri siswa yang hanya akan bereaksi seteleh adanya stimulus dari guru. Disisi lain, peran guru senantiasa harus memberikan penguatan (reinforcement) bagi siswanya. Hal ini ditujukan agar siswa mampu termotivasi dalam pembelajaran. Penguatan yang dilakukan guru bisa dilaksanakan secara kondisional, artinya siswa diberlakukan penguatan juga dapat dilakukan secara situasi dan kondisi pada siswa. Kondisi tersebut meliputi kondisi pada aspek preventif (pencegahan) berupa anjuran dan nasihat, serta aspek koersif (sanksi/denda) berupa hukuman yang bersifat mendidik bagi siswa 
(bukan hukuman fisik). Penguatan yang bersifat kondisional ini merupakan prinsip dari pembelajaran tipe operant conditioning.

Skinner menganggap "reward" atau "reinforcement" sebagai faktor terpenting dalam proses belajar. Skinner berpendapat, bahwa tujuan psikologi adalah meramal dan mengontrol tingkah laku. Skinner membagi dua jenis respon dalam proses belajar, yakni: Respondens (respon yang terjadi karena stimulus khusus misalnya Pavlov) dan Operants (respon yang terjadi karena situasi random). (Hill, 2012:98).

Selanjutnya, Skinner membagi penguatan ini menjadi dua yaitu penguatan positif dan penguatan negatif. Bentuk bentuk penguatan positif berupa hadiah, perilaku, atau penghargaan. Bentuk bentuk penguatan negatif antara lain menunda atau tidak memberi penghargaan, memberikan tugas tambahan atau menunjukkan perilaku tidak senang.

Implikasi beberapa prinsip belajar Skinner di atas, bahwa peran guru harus menunjukan hasil belajar untuk segera diberitahukan kepada siswa dengan tujuan jika salah dibetulkan, jika benar diberi penguatan. Penguatan dalam proses pembelajaran, tidak menggunakan hukuman. Untuk itu lingkungan perlu diubah, untuk menghindari adanya hukuman dalam proses pembelajaran, dan yang lebih dipentingkan aktifitas sendiri. Tingkah laku yang diapresiasikan oleh pendidik yaitu memberi hadiah, dan sebaiknya hadiah diberikan dengan digunakannya jadwal variabel rasio reinforcerment-nya. Pembelajaran dengan pola demikian, guru dalam menyampaikan materi yaitu menggunakan sistem pembelajaran modul.

Belajar empirisme juga memiliki pengaruh atau dampak pada proses belajar secara pengamatan. Artinya, siswa mengetahui, memahami, dan menyerap melalui obyek-obyek tertentu yang dilakukannya melalui pengamatan. Pengamatan atau observasi ini dapat berguna mengasah skill (keterampilan) siswa dan juga dapat mengarahkan pada bentuk perilaku tertentu, khususnya perilaku yang baik. Sebagai contoh siswa, diperlihatkan sekelompok orang yang sedang mengantri di kasir, atau di POM Bensin. Tipe pembelajaran ini mengarah pada tipe observational Learning.

Menurut Nana Sudjana (2010: 22), hasil belajar adalah kemampuan yang dimiliki siswa setelah menerima pengalaman belajar. Selanjutnya Warsito (dalam Depdiknas, 2006: 125) mengemukakan bahwa hasil dari kegiatan belajar ditandai dengan adanya perubahan perilaku ke arah positif yang relatif permanen pada diri orang yang belajar. Sehubungan dengan pendapat itu, maka Wahidmurni, dkk. (2010: 18) menjelaskan bahwa sesorang dapat dikatakan telah berhasil dalam belajar jika ia mampu menunjukkan adanya perubahan dalam dirinya. Perubahan-perubahan tersebut di antaranya dari segi kemampuan berpikirnya, keterampilannya, atau sikapnya terhadap suatu objek.

Pengaruh berikutnya dari aliran empirisme ini yaitu proses pembelajaran siswa dilakukan menurut tahapan atau tingkatan tertentu. Tipikal pembelajaran ini disebut Hierarchial Learning. Struktur perilaku yang 
hierarkikal adalah kedudukan dua perilaku yang menunjukkan bahwa perilaku hanya dapat dilakukan bila telah dikuasai perilaku yang lain. Perilaku B misalnya, hanya dapat dipelajari bila siswa telah dapat melakukan perilaku A. Kedudukan A dan B disebut hierarkikal. Dalam suatu kurikulum, mata pelajaran A merupakan prasyarat untuk mengikuti pelajaran $\mathrm{B}$, atau Kompetensi Dasar (KD) A merupakan prasyarat untuk mengikuti Kompetensi Dasar (KD) B. Tanpa lulus KD A siswa tidak boleh atau tidak mungkin langsung mengikuti KD B.

Perhatikan beberapa contah perilaku di berikut: pertama kedudukan perilaku mengamati jaringan tumbuhan dan memahami sel tumbuhan. Adapun kegiatan pembelajaran meliputi beberapa aspek: pertama mengamati jaringan tumbuhan seperti mengamati sel penyusun, bentuk sel penyusun, ukuran sel penyusun tidak mungkin dilakukan bila siswa belum memahami tentang sel tumbuhan, kedua mengamati jaringan tumbuhan, ketiga memahami pengertian sel tumbuhan. Ketiga perilaku tersebut tersusun secara hierarkikal. Memahami pengertian sel tumbuhan merupakan prasyarat untuk dapat mengamati jaringan tumbuhan. Kedua Kedudukan perilaku mengambil keputusan terhadap perilaku manganalisis alternatif pemecahan masalah. Artinya, perilaku mengambil keputusan untuk memecahkan masalah tertentu hanya dapat dilakukan bila sudah menguasai cara melakukan analisis alternatif yaitu teknik membandingkan berbagai alternatif pemecahan masalah dari berbagai segi seperti segi efisiensi dan efektivitas berupan mengambil keputusan dan analisis alternatif.

Setiap contoh di atas dapat diteruskan dengan menambah kotak di bawah atau di atas kedua kotak yang telah ada. Untuk menunjukkan struktur hierarkikal, kotak tambahan harus menunjukkan perilaku prasyaratnya (bila di bawah) atau perilaku yang lebih tinggi tingkatannya (bila di atas). Untuk menunjukkan struktur perilaku hierarkikal yang berbeda dengan struktur yang lain, kedua kotak dalam setiap kotak tadi disusun atas-bawah dan dihubungkan dengan garis vertikal (Atwi S, 2001: 62).

Pandangan empirisme yang membutuhkan sikap dan peran aktifnya seorang guru/pendidik merupakan tugas dan kewajiban sebagai pengarah pembelajar untuk mewujudkan siswa lebih aktif dalam proses pembelajaran. Hal ini berlawanan dengan aliran pendidikan ke-dua yang akan penulis deskripsikan berikut ini yaitu mengenai konsep nativisme dan naturalisme.

Pandangan aliran nativisme dan naturalism menyatakan pendidikan sebagai bagian dari sifat pembawaan dan faktor alami manusia (individu) siswa. Aliran nativisme berpandangan segala sesuatunya ditentukan oleh faktor-faktor yang dibawa sejak lahir, jadi perkembangan individu itu semata-mata dimungkinkan dan ditentukan oleh dasar turunan. Misalnya jika ayahnya pintar, maka kemungkinan besar anaknya juga pintar. Para penganut aliran nativisme berpandangan bahwa bayi itu lahir sudah dengan pembawaan baik dan pembawaan buruk. Oleh karena itu, hasil akhir pendidikan ditentukan oleh pembawaan yang 
sudah dibawa sejak lahir. Berdasarkan pandangan ini, maka keberhasilan pendidikan ditentukan oleh anak didik itu sendiri. Ditekankan bahwa "yang jahat akan menjadi jahat, dan yang baik menjadi baik". Pendidikan yang tidak sesuai dengan bakat dan pembawaan anak didik tidak akan berguna untuk perkembangan anak sendiri dalam proses belajarnya. Bagi nativisme, lingkungan sekitar tidak ada artinya sebab lingkungan tidak akan berdaya dalam mempengaruhi perkembangan anak. Penganut pandangan ini menyatakan bahwa jika anak memiliki pembawaan jahat maka dia akan menjadi jahat, sebaliknya apabila mempunyai pembawaan baik, maka dia menjadi orang yang baik. Pembawaan buruk dan pembawaan baik ini tidak dapat dirubah dari kekuatan luar.

Pengaruh atau implikasinya dalam dunia pendidikan senada dengan argumen yang penulis kutip dari Prof.Sunardi bahwa "proses belajar harus mengikuti irama dari yang belajar". Irama dari yang belajar merupakan berdampak pada proses dan hasil belajar siswa di kelas. Sehingga pada implikasi berikutnya salah satunya bahwa individu memiliki irama perkembangannya masing-masing. Pembelajaran pada aliran ini bisa disebut sebagai tipe psikologi kognitivisme. Karena pada dasarnya individu tercipta dari pribadi yang heterogen dengan tahapan pertumbuhan dan perkembangan yang bervariasi setiap tahapannya.

Aliran pendidikan dengan teori nativisme dan naturalism memiliki pandangan bahwa manusia itu semuanya mempunyai pembawaan yang baik. Pelopor teori ini adalah J.J Rosseau Ia berpedapat dalam bukunya Emile: bahwa "Semua anak adalah baik pada waktu baru datang dari tangan sang pencipta, tetapi semua menjadi buruk di tangan manusia”. Aliran ini disebut juga aliran negativisme, karena pendidik hanya wajib membiarkan pertumbuhan anak didik dengan sendirinya atau diserahkan kembali kelingkungannya (alam). Dengan kata lain, anak tidak memerlukan pendidikan tetapi yang perlu dilakukan oleh seorang pendidik terhadap anak didiknya adalah menyerahkannya ke alam, agar pembawaan yang baik itu tidak menjadi rusak melalui proses kegiatan pendidikan itu.

Berikut ini implikasi dari masing-masing tipe dari aliran nativisme dan naturalism berdasarkan tokoh-tokoh perkembangan individu (Elliot, S. N, et al., 2000: 79-133).

\section{Pertama, Implikasi}

Teori

\section{Perkembangan Kognitif dari Vygotsky.}

Pembelajaran akan lebih efektif tatkala seorang guru mengajar dengan menggunakan teori Vygotsky sebagai landasan, bentuk pembelajaran yang dimaksud adalah: sebelum mengajar, seorang guru hendaknya dapat memahami Zone of Proxsimal Development (ZPD). Zone of proximal development (ZPD) adalah serangkaian tugas yang terlalu sulit dikuasai anak secara sendirian, tapi dapat dipelajari dengan bantuan orang dewasa atau anak yang lebih mampu. Guru memahami khususnya siswa batas bawah sehingga bermanfaat untuk menyusun struktur mteri pembelajaran. Implikasinya guru lebih akuat tatkala menyusun strategi mengajarnya, sehingga tidak melulu selalu memberikan bimbingan kepada siswa. Dampak pengiringnya 
adalah siswa dapat belajar sampai tingkat keahlian yang diharapkan dan mencapai ZPD pada batas atas. Selanjutnya Untuk mengembangkan pembelajaran yang komunitas seorang guru perlu memanfaatkan tutor sebaya didalam kelas, serta didalam pembelajaran seorang guru hendaknya menggunakan teknik scaffolding dengan tujuan siswa dapat belajar atas inisiatifnya sendiri, sehingga mereka dapat mencapai keahlian pada batas atas ZPD.

\section{Kedua, Implikasi Teori Perkembangan}

Kognitif dari Piaget. Implikasinya yaitu: pertama; karena cara berpikir anak itu berbedabeda dan kurang logis di banding dengan orang dewasa, maka guru harus dapat mengerti cara berpikir anak, bukan sebaliknya anak yang beradaptasi dengan guru. Kedua; anak belajar paling baik dengan menemukan (discovery). Artinya disini adalah agar pembelajaran yang berpusat pada anak berlangsung efektif, guru tidak meninggalkan anak-anak belajar sendiri, tetapi mereka memberi tugas khusus yang dirancang untuk membimbing para siswa menemukan dan menyelesaikan masalah sendiri. Ketiga; Pendidikan disini bertujuan untuk mengembangkan pemikiran anak, artinya ketika anak-anak mencoba memecahkan masalah, penalaran merekalah yang lebih penting daripada jawabannya. Oleh sebab itu guru penting sekali agar tidak menghukum anak-anak untuk jawaban yang salah, tetapi sebaliknya menanyakan bagaimana anak itu memberi jawaban yang salah, dan diberi pengertian tentang kebenarannya atau mengambil langkah-langkah yang tepat untuk untuk
4)Guru dapat menemukan menemukan dan menetapkan tujun pembelajaran materi pelajaran atau pokok bahasan pengajaran tertentu.

Ketiga, Implikasi Teori Perkembangan Psikososial dari Erikson. Implikasi dari Erikson yaitu tentang peran sekolah sebagai lembaga pendidikan formal yang diserahi tugas untuk mendidik, tidak kecil peranannya dalam rangka mengembangkan hubungan sosial peserta didik. Jika dalam hal ini guru tetap berpegang sebagai tokoh intelektual dan tokoh otoritas yang memegang kekuasaan penuh seperti ketika anakanak belum menginjak remaja, maka sikap sosial atau hubungan sosial anak akan sulit untuk dikembangkan. Untuk itu rambu-rambu berikut dapat digunakan sebagai titik tolak untuk pengembangan hubungan sosial peserta didik: 1)Sekolah harus merupakan dasar untuk perkembangan kepribadian peserta didik. 2)Saling menghargai merupakan kunci yang dapat digunakan untuk menanggulangi masalahmasalah yang timbul dalam hubungan dengan peserta didik yang bertabiat apapun. 3)Pola pengajaran yang demokratis merupakan alternatif yang sangat bermanfaat bagi guru.

\section{Keempat, Implikasi}

Teori

\section{Perkembangan Moral dari Kohlberg.} Implikasi-implikasi dari sifat-sifat dalam teori perkembangan moral Kohlberg seperti berikut ini: pertama; Perkembangan terjadi langkah demi langkah, artinya, tahap-tahap itu bersifat invarian. Kedua; perkembangan dapat berhenti pada tahap manapun. Peranan pendidik adalah menciptakan kondisi yang memberikan stimulasi supaya setiap individu dapat berkembang secara maksimum, 
terutama dengan menstimulasikan tingkatantingkatan penalaran yang lebih tinggi. Ketiga; Seorang individu dapat tertarik oleh penalaran dari suatu tahap di atas tahap yang secara dominan mewarnainya. Keempat; perkembangan kognitif perlu, tetapi tidak merupakan kondisi yang mencukupi untuk perkembangan moral. Kemampuan berpikir abstrak adalah esensial untuk mendapatkan alternatif-alternatif dalam penalaran moral dan esensial untuk menyusun prioritas dalam bermacam-macam nilai. Kelima; norma etika dan empati juga perlu, tetapi bukan kondisi yang mencukupi untuk perkembangan moral. Justru dengan empati inilah orang memperkembangkan suatu pengertian mengenai apakah masyarakat itu dan mulai menilai tindakan sebagai benar atau salah atas dasar rasa hormat timbal balik.

Kelima, Implikasi Teori Perkembangan Bahasa. Ada beberapa ciri aplikasi pembelajaran humanistik di kelas. Ciriciri tersebut adalah 1)memberi kesempatan seluasnya agar siswa mengembangkan diri secara potensi, pribadi, sikap, berkembang menuju taraf yang lebih baik/sempurna, 2)Adanya proses pemanusiaan manusia dan menghargai pendapat orang lain (karena tahu etika berbahasa yang baik dan benar). 3) Siswa memiliki peran. 4)Proses yang berlangsung adalah pembelajaran bukan pengajaran.

\section{Keenam, Implikasi dari Benyamin}

Bloom. Implikasi Bloom dengan tahapan C1, C2, C3, C4, C5, dan C6 nya bermanfaat pada: 1)Siswa memiliki tahapan belajar dari yang mudah hingga sulit (sukar). 2)Siswa belajar dari definisi hingga pada pembedaan dan evaluasinya. 3)Siswa belajar mulai dari hafalan, pemahaman, analisis, aplikasinya, sintesanya, dan mengevaluasi. Atau jika dikaji lebih mendalam, maka hasil belajar dapat tertuang dalam taksonomi Bloom, yakni dikelompokkan dalam tiga ranah (domain) yaitu domain kognitif atau kemampuan berpikir, domain afektif atau sikap, dan domain psikomotor atau keterampilan. Sehubungan dengan itu, Gagne (dalam Sudjana, 2010: 22) mengembangkan kemampuan hasil belajar menjadi lima macam antara lain: (1) hasil belajar intelektual merupakan hasil belajar terpenting dari sistem lingsikolastik; (2) strategi kognitif yaitu mengatur cara belajar dan berfikir seseorang dalam arti seluas-luasnya termaksuk kemampuan memecahkan masalah; (3) sikap dan nilai, berhubungan dengan arah intensitas emosional dimiliki seseorang sebagaimana disimpulkan dari kecenderungan bertingkah laku terhadap orang dan kejadian; (4) informasi verbal, pengetahuan dalam arti informasi dan fakta; dan (5) keterampilan motorik yaitu kecakapan yang berfungsi untuk lingkungan hidup serta memprestasikan konsep dan lambang.

Ketujuah, Implikasi dari Guilford, yaitu 1)Siswa memiliki keragaman atau variasi perkembangan dan pola pikirnya. 2)Siswa dikotakan dalam tipe yang berbeda-beda sebagai susunan yang dapat dibentuk menjadi susunan kelompok yang seragam (sama).

\section{Kedelapan, Implikasi dari Goleman,} yaitu: 1)Siswa memiliki kecerdasan berbeda-beda peran guru mengetahui kemampuan dan potensi yang dimiliki oleh siswanya. 2)Guru 
mengarahkan dan mendorong serta menggali bakat, kemampuan, pada siswa.

\section{Kesembilan, Implikasi lain dalam} Aliran Nativisme dan Naturalisme yaitu: siswa diarahkan untuk dapat berpikir studi kasus dengan pemecahan masalahnya berupa berpikir problem solving, kritis (Critichal Thinking), Reflective Thinking dan Initiative Thinking.

Berikutnya mengakhiri dari aliran klasik dalam pendidikan, muncul aliran pendidikan yang ketiga, yaitu Konvergensi. Aliran ini merupakan penggabungan dari aliran empirisme dan naturalism serta nativisme yang menghendaki adanya kebebasan pada siswa. Kebebasan tersebut merujuk pada tingkatan kebutuhan anak itu sendiri (Abraham Maslow) yang meiputi: 1)Kebutuhan fisik, 2)Kebutuhan keamanan, 3)Kebutuhan cinta, kasing saying dan kepemilikan, 4)Kebutuhan esteem (harga diri), 4)Kebutuhan aktualisasi diri.

Dikarenakan penggabungan dua aliran sebelumnya, teori kovergensi merupakan gabungan antara teori empirisme dan nativisme antara pembawaan dan pendidikan yang harus sejalan beriringan satu sama lainnya. Islam mengajarkan kepada kita seperti dalam sabda Rasulullah "Setiap Anak dilahirkan dalam keadaan fitrah tergantung orang tuanyalah yang akan menjadikan dia menjadi yahudi,nasrani atau majusi (H.R.Bukhari). Selain itu juga terjabarkan dalam firman Allah bahwa fitrah Allah yang menciptakan manusia menurut fitrah itu. (Hukum-hukum) ciptaan Allah tidak dapat diubah. Itulah agama yang benar. Tapi sebagian besar manusia tidak mengetahui (QS Ar Rum
:30). Hal inilah menyatakan bahwa Rasulullah juga mengajarkan kepada kita kalau mau memiliki keturunan yang baik. Rasulullah bersabda: Nikahilah perempuan itu karena kecantikannya, keturunannya, kekayaannya dan karena agamanya dan pilih yang demikian itu karena agamanya supaya kamu beruntung (HR. Bukhori Muslim).

Jika diidentifikasi teori tersebut, maka jelas bahwa unsur nativisme dan empirisme membangun kedua teori itu. Hal itu tercermin pada faktor bakat merupakan gagasan teori nativisme sedangkan faktor lingkungan merupakan gagasan empirisme. Penganut aliran ini berpendapat bahwa dalam proses perkembangan anak, baik faktor pembawaan maupun faktor lingkungan sama-sama mempunyai peran yang sangat penting. Bakat yang dibawa pada waktu anak tersebut dilahirkan tidak akan berkembang dengan baik tanpa adanya dukungan lingkungan yang baik sesuai dengan perkembangan bakat anak itu. Sebaliknya, lingkungan yang baik tidak akan menghasilkan perkembangan anak yang optimal kalau memang pada diri anak itu tidak terdapat bakat yang diperlukan untuk dikembangkannya. Sebagai ilustrasi, anak dalam tahun pertama mempelajari bahasa bukan karena dorongan dan bakat. Melainkan karena meniru suara ibunya dan orang-orang di sekitarnya. Namun, tanpa ada bakat dan dorongan, tentu saja hal itu tidak dimungkinkan. Sehingga kedua aspek ini sama pentingnya. Sebagai gambaran lain, seorang yang memiliki bakat bermain musik, namun karena 
lingkungan tidak mengkondisikan orang tersebut, maka ia pun tidak akan menjadi pemusik hebat.

Karena itu teori William Stern yang merupakan tokoh teori konvergensi mengartikan pada makna konvergen artinya memusat kesatu titik. Satu titik pusatnya ada pada arah pendidikan diartikan sebagai pertolongan yang diberikan lingkungan kepada anak didik untuk mengembangkan potensi yang baik dan mencegah berkembangnya potensi yang kurang baik. Kemudian, yang membatasi hasil pendidikan adalah pembawaan dan lingkungan.

Implikasi pada aliran konvergensi ini yaitu kebutuhan pada kebebasan ini melahirkan pada metode, media, sumber belajar, evaluasi pembelajaran siswa semakin bervariasi. Oleh sebab itu, guru dan siswa dituntut aktif dan kreatif serta inovatif.

Seperti telah dikemukakan bahwa variasi-variasi itu tercermin antara lain dalam perbedaan pandangan tentang strategi yang tepat untuk memahami perilaku manusia, contohnya seperti strategi phenomenologis/ humanistic, startegi behavior, psiko analitik, dan sebagainya. Demikian pula halnya dalam belajar mengajar; variasi pendapat itu telah menyebabkan munculnya berbagai teori belajar mengajar dan atau teori/model mengajar. Sebagai contoh dikenal berbagai pendapat tentang modelmodel mengajar seperti rumpun model behavior (umpan model belajar tuntas, model belajar kontrol diri sendiri, model belajar simulasi, dan model belajar asertif), model belajar pemmrosesan informasi (model belajar inkuiri, model persentase kerangka dasar, atau advance organizer, dan model pengembangan berfikir), dan lain-lain.

Dari sisi-sisi lain, variasi pendapat itu juga melahirkan berbagai pendapat gagasan tentang belajar mengajar, seperti peran guru sebagai fasilitator atau informatory, teknik penilaian pencapaian siswa dengan tes objektif atau tes esai, perumusan tujuan pengajaran yang sangat behavior, penekanan pada peran teknologi pengajaran dan pembelajaran yang semakin bervariasi, kreatif dan inovatif.

\section{DAFTAR PUSTAKA:}

Arief Furqon. 1992. Pengantar Metode Penelitian Kualitatif. Surabaya: Usaha Nasional.

Atwi Suparman, M. 2001. Desain Instruksional. Jakarta : PAU-PPAI-UT.

Depdiknas. 2006. Bunga Rampai Keberhasilan Guru dalam Pembelajaran (SMA, SMK, dan SLB). Jakarta: Depdiknas.

Departemen Agama Republik Indonesia. 2006. AlQur'an dan terjemahannya. Surabaya: Pustaka Agung Harapan.

Elliot, S. N, et al. 2000. Educational Psycology: Effective Teaching, Effective Learning. Singapore: Brown\&Benchmark.

Hill. W.F. 2012. Theories of Learning; Teori-Teori Pembelajaran. Bandung: Nusa Media.

HR.Bukhori Muslim (http://www.yuwonoputra.com/2013/07/-teoriperkembangan $30 . \mathrm{html}$, Diunduh pada tanggal 4 September 2016, pukul 20.30 WIB).

Meidawati Suswandari. 2015. Inovasi dan Analisis Kebijakan Pendidikan. Sukoharjo: CV Jasmine. 
2016. Sosiologi Pendidikan (Pendekatan Teori dan Studi Kasus). Semarang: UPGRIS.

Muhaimin, dkk 2002. Paradigma Pendidikan Islam; Upaya Mengefektifkan Pendidikan Agama Islam di Sekolah, Cet. II. Bandung: Remaja Rosda Karya.

M. Hamid 2002. Pendekatan Psikologis dalam Proses Belajar Bahasa. Surabaya: Fak. Adab IAIN Sunan Ampel.
M.Z Roziqin. 2007. Moral Pendidikan di Era Global; Pergeseran Pola Interkasi Guru-Murid di Era Global. Malang: Averroes Press.

Nana Sudjana. 2010. Penilaian Hasil Proses Belajar Mengajar. (Cet. XV). Bandung: Remaja Rosdakarya.

Wahidmurni, Alifin Mustikawan, dan Ali Ridho. 2010. Evaluasi Pembelajaran: Kompetensi dan Praktik. Yogyakarta: Nuha Letera.

W. Sanjaya. 2006. Strategi Pembelajaran Berorientasi Standar Proses Pendidikan. Jakarta: Kencana. 